\title{
As cores do crepúsculo: fabulação, teologia e literatura em Rubem Alves
}

\author{
Anaxsuell Fernando da Silva
}

\section{Resumo}

Este artigo é o desdobramento de investigação a respeito da vida de Rubem Alves (1933-2014), teólogo, psicanalista, escritor, cronista e educador brasileiro para tese doutoral. Neste texto, de maneira específica, discute-se o percurso intelectual desse autor no que tange à sua singularidade - de teólogo da libertação a cronista do cotidiano e escritor de contos infantis. Contrastamos suas publicações acadêmicas com seus escritos literários para sugerir uma kenosis estética ao longo de sua trajetória. Isto é, a produção teológica de Rubem Alves esteve inicialmente sustentada em perspectivas sociológicas, no âmbito do humanismo político. E, ao longo de suas travessias transformou-se numa teologia heterodoxa, poética com ênfase na magia, utopia e imaginação. Nesse sentido, problematizamos a relação entre sujeito e realidade externa expressa por sua capacidade de construir novos mundos, atribuir novos sentidos à vida, abrir-se ao simbólico e ao devir; e não, pelo adaptar-se passivamente à realidade exterior submetendo-se a ela.

Palavras-chave: Rubem Alves. Literatura. Teologia. Fabulação.

\section{The Colors of Twilight: Fables, Theology, and Literature in Rubem Alves}

\section{Abstract}

This article is unfolding research on the life of Rubem Alves (1933-2014), theologian, psychoanalyst, writer, columnist and Brazilian educator for doctoral thesis. In this text, specifically, discusses the intellectual journey this author with respect to its uniqueness - of the liberation theologian daily columnist and writer of children's stories. Contrasted his academic publications to his literary writings to suggest an aesthetic kenosis throughout his career. That is, the theological production Rubem Alves was initially sustained in sociological perspectives within the political humanism. And throughout

\footnotetext{
* Universidade Federal da Integração Latino-Americana. Doutor em Ciências Sociais pela Universidade Estadual de Campinas (Unicamp). Professor de Antropologia na Universidade Federal da Integração Latino-Americana. anaxsfernando@yahoo.com.br
} 
their crossings it was becoming a heterodox theology, emphasizing the poetic magic, utopia and imagination. In this sense, we question the relationship between subject and external reality begins to express itself in its ability to build new worlds, to assign new meanings to life and to open up to the symbolic and to the process of becoming, rather than passively surrendering to external reality.

Key-words: Rubem Alves. Literature. Theology. Ffabulation.

\section{Los colores del crepúsculo: fabulación, teología y literatura en Rubem Alves}

\section{Resumen}

Este artículo es resultado de investigación de la vida de Rubem Alves (1933-2014), teólogo, psicoanalista, escritor, cronista y educador brasileño, hecha para una tesis de doctorado. En este texto se discute la trayectoria intelectual de ese autor, sobre su singularidad, de teólogo de la liberación a cronista de lo cotidiano y escritor de cuentos infantiles. Contrastaos sus publicaciones académicas con sus escritos literarios para sugerir una kenosis estética a lo largo de su trayectoria. La producción teológica de Rubem Alves estuvo inicialmente sustentada en perspectivas sociológicas, en el ámbito del humanismo político. Y a lo largo de sus travesías se transformó en una teología heterodoxa, poética, con énfasis en la magia, utopía e imaginación. En ese sentido problematizamos la relación entre sujeto y realidad externa clara en su capacidad de construir nuevos mundos, atribuir nuevos sentidos a la vida, abrirse a lo simbólico y al devenir; y no, por adaptarse pasivamente a la realidad exterior sometiéndose a ella. Palabras clave: Rubem Alves. Literatura. Teología. Fabulación.

O pôr-do-sol é metáfora poética, e se o sentimos assim, é porque sua beleza triste vive em nosso corpo. Somos seres crepusculares. É por isso que essa é a hora do terror noturno, quando as pessoas recordando-se de seu parentesco com as aves, regressam ansiosas para casa e acendem as luzes que não se apagam. ${ }^{1}$

\section{Introdução}

A obra de Gastón Bachelard possui uma tênue distinção que vários estudiosos habitualmente classificam de diurna e noturna. O Bachelard diurno compreende as obras epistemológicas, as quais fizeram desse autor um crítico do racionalismo e do empirismo científico. Já seus escritos nomeados como noturnos são aqueles em que a imaginação, a arte e a poética ocupam a centralidade.

Essas duas vertentes do legado bachelardiano têm ocupado seus críticos. Esses se perguntam da dualidade inconciliável ou da unidade funcional e dinâmica de sua obra. Há os que assinalam o dualismo dia/noite, ${ }^{2}$ metáforas visualmente

\footnotetext{
$1 \quad$ Alves, Rubem. Tempus Fugit, 1997, p. 54.

2 Lecourt, D. Bachelard: Le Jour et la Nuit. Paris: Grasset, 1974.
} 
excludentes e antagônicas. A face solar seria desfavorável à face lunar, opondo, desse modo, os mundos da ciência e da poética.

A despeito da disrupção, Gaston Bachelard também é o homem das 24 horas: "Esse homem 'uni-dual', que se opõe e se complementa a cada 12 horas, andrógino que sutura os delineamentos das duas franjas do pensamento" (FREITAS, 2006). Essa alusão ao homem das 24 horas foi feita por Bachelard em conferência à Sociedade Francesa de Filosofia, em 1950, quando estava com 66 anos de idade. Naquela ocasião, mencionou ser um filósofo no outono de sua vida e que tinha "nostalgia de uma certa antropologia".

Não foi fortuitamente que Rubem Alves afirmou de modo categórico: "Bachelard é o escritor que eu invejo de verdade". À semelhança do filósofo francês, o espectro da vasta produção bibliográfica alvesiana vai da luminosidade à opacidade, e sem esquivar-se das sombras. $\mathrm{O}$ autor de Filosofia da ciência: introdução ao jogo e suas regras, um dos livros mais lidos entre os recémingressos nas universidades brasileiras, o qual defende a necessidade do rigor acadêmico; é o mesmo a escrever:

Minha teologia nada tem a ver com teologia. É vício. Há muito que deveria ter abandonado este nome. E dizer só poesia, ficção. Descansem os que têm certezas. Não entro no seu mundo e nem desejo entrar. Jardins de concreto me causam medo. Prefiro a sombra dos bosques e o fundo dos mares, lugares onde se sonha... Ali moram os mistérios e o meu corpo fica fascinado (ALVES, 1987).

\section{Rubem: cores e travessias}

Rubem Alves foi, sobretudo, um ser capaz de efetuar travessias, talentoso em morrer e renascer; ou, para utilizar uma expressão bioniana, Rubem Alves, em sua trajetória de vida foi capaz de "mudar de mundos", e de viver "mudanças catastróficas". Neste artigo, nos dedicaremos às passagens ou travessias em sua obra objetivada, isto é, nos seus escritos. Em outros trabalhos, temos nos ocupado das passagens subjetivas na sua compreensão de mundo.

A teologia de Rubem Alves experimentou o que poderíamos chamar de Kenosis estética. A palavra grega aqui utilizada é uma herança da Patrística Oriental, a qual se refere ao movimento, da dinamicidade de Deus que vem ao encontro do humano. Para os orientais, o conhecimento só se dá no relacionamento. Portanto, Deus, para ser conhecido e conhecer o humano, deve ir ao encontro desse humano, relacionar-se com ele, e se dar a relacionar. Assim, Kénosis é o sair de si sem deixar

\footnotetext{
Cf. Cervantes-Ortiz, 2005.
} 
de ser o "si" mesmo. É um autoesvaziamento. É se esvaziar para se encontrar no outro, sem perder a própria identidade. $\mathrm{Na}$ Teologia contemporânea, Kénosis “[...] significa a pessoa despojar-se, por amor, do que lhe é próprio, dar-se totalmente para fazer-se um com os outros, para viver o outro, para permitir que o outro se realize e, desse modo, colocar as condições para ser plenamente ele próprio". ${ }^{4}$

Dito de outra maneira, a produção teológica de Rubem Alves esteve inicialmente sustentada em perspectivas sociológicas, ${ }^{5}$ no âmbito do humanismo político. E, ao longo de suas travessias transformou-se numa teologia heterodoxa, poética com ênfase na magia, utopia e imaginação. Temos - para utilizar a mesma imagem empregada a Bachelard - uma teologia diurna e uma teologia noturna ou crepuscular. E o percurso de uma a outra se dá pelo esvaziamento, pelo aniquilamento daquilo que a teologia considera mais cara: seu caráter concreto, totalizante e explicativo. Esvaziamento que se expressa, antes de tudo, na eliminação da linguagem acadêmica para que a própria teologia possa fazer-se conhecida.

Em sua teologia diurna, Rubem Alves parte da crítica direcionada aos aspectos a-históricos das teologias nascidas no norte-atlântico e percebe a libertação humana acontecendo no chão da história. No humanismo messiânico - expressão utilizada pelo próprio Rubem -, Deus (autor) e o ser humano (coautor) lutam para a transformação do mundo em uma ordo amoris. ${ }^{6}$

A despeito das críticas de muitos, o teólogo mineiro está entre os fundadores da Teologia da Libertação na América Latina. A interiorização de todo pensamento crítico ocidental e sua aguda percepção das estruturas de opressão e dominação, legitimadas pelos corruptos "sacerdotes" do século XX, fizeram de Rubem uma importante voz protestante na gênese de uma profunda consciência histórica de libertação. ${ }^{7}$

Xavier, 2007, p. 87.

A esse respeito cabe consultar o artigo Da Teologia da Libertação à libertação da teologia: a biografia de um intelectual protestante publicado na Revista Brasileira de História das Religiões (Cf. SILVA, 2017).

6 Sobre esse aspecto particular, Rainerson Luiz escreveu sua dissertação de mestrado em Teologia pela PUC-Rio, defendida em 2012, a qual recomendo para ulterior aprofundamento dessa trilha que não será explorada neste artigo.

As contribuições de Alves entre os textos significativos da Teologia da Libertação, não se restringem à sua tese de doutorado Towards a Theology of Liberation. Lembramo-nos da sua contribuição à edição famosa preparada por Rosino Gibellini intitulada "La nueva frontera de la teologia em America Latina" na qual estão incluídos artigos como "La liberación de Cristo" de G. Gutiérrez, "Liberación de Jesuscristo por el camino de la presión" de L. Boff, "Praxis histórica e identidad cristiana" de José Miguez Bonino, "Capitalismo-socialismo, crux theologica" de Juan Luis Segundo e tantos outros. Alves, nesse livro, escreveu um artigo intitulado "Del paraíso al desierto" (Cf. GIBELLINI, R. La Nueva Frontera de la Teologia em America Latina. Salamanca: Sígueme, 1975, p. 261-279). 
Enrique Dussel ${ }^{8}$ nota a importância histórica dessa produção teórica no engendramento de uma consciência emancipatória. Em seu livro História da Igreja Latino-Americana (1930-1985), ele afirma: "Só em 1968, como já dissemos, aparecem as primeiras obras de Teologia da Libertação propriamente ditas, como as de Rubem Alves, Richard Shaull, Gustavo Gutiérrez, Hugo Assmann em 1970 ou Lúcio Gera" (DUSSEL, 1989, p. 74-75).

$\mathrm{O}$ aspecto distintivo de Rubem Alves em relação a esses outros importantes pensadores está na percepção singular da alegria, do corpo, do sentido erótico da vida, aspecto não contemplado por qualquer teólogo. Entretanto, é essa percepção que torna sua produção teológica depreciada pelos revolucionários oriundos do marxismo ortodoxo.

Causava incômodo à estrutura eclesial a compreensão do ser humano em Alves, marcada pelo conselho de Zaratustra que, após dez anos de solidão nas montanhas, desceu-as e proclamou: "Exorto-vos, meus irmãos, a permanecer fiéis à terra e a não acreditar em quem vos fala de esperanças supraterrestres".

O discurso eclesial refere-se à transcendência. Algo que não se expressa da vida material. Ou seja, não se trata de uma realidade em meio à vida, mas uma realidade para além da vida. A linguagem eclesial aparta o tempo da eternidade, distingue a transcendência da História. A transcendência, a partir de tal prisma, torna-se uma verdade maior, acima e além da História. Portanto, a teologia diurna de Rubem Alves, nos mesmos caminhos do humanismo político, rompeu com esse discurso eclesial-teológico hegemônico. Para ele, a consciência "não se expande na direção de um novo amanhã, mas tenta se mover para o alto, rumo à experiência de um reino transcendente, localizado além da matéria e do tempo: a esfera espiritual e eterna" (ALVES, 1987, p. 74).

Enquanto, hegemonicamente, no protestantismo, a libertação humana está nas mãos de Deus, no bojo do projeto político alvesiano de libertação humana, as esperanças que não estão arraigadas no chão da História são desnecessárias e sequer poderiam ser chamadas de esperança, já que mais se alinham como novas formas de alienação e ilusão.

O ser humano na teologia de Alves é um co-criador. A criação de um novo amanhã consiste num empreendimento conjunto entre o ser humano e Deus. Deus, na linguagem do humanismo messiânico, está envolvido com a política

Filósofo argentino, atua como pesquisador na Universidade Autônoma do México. Tem sido considerado um dos maiores expoentes da Filosofia da Libertação e do pensamento latino-americano em geral.

9 Nietzsche, F. Assim falou Zaratustra, p. 25. 
de libertação. Ele não olha a história a partir de seu futuro e nem a arrasta de lá. É na história que Deus e o homem engendram um futuro comum.

Esse tema, a libertação, seria revisitado por Rubem no livro Tomorrow's Child, sob o impacto das frustrações que esse autor enfrentou no Brasil. Como já mencionei, este livro resultou do período em que atuou como professor visitante no Union Theological Seminary, em New York; e talvez seja preciso reforçar que as reflexões contidas nele sucedem o rompimento de Rubem Alves com a Igreja Presbiteriana do Brasil. Acontecimento que marca o seu crepúsculo teológico.

Os argumentos dessa obra seguem a linha configurada na Theology of Human Hope. Contudo, distanciado da luminosidade diurna própria aos outros teólogos da libertação humana, Alves aposta na experiência lúdica, na magia, na beleza e na corporeidade. A preterência das categorias marxistas - como dialética e luta de classes - seria fartamente alvo de crítica dos teólogos da Libertação.

Não à toa, no prefácio escrito por Rubem quinze anos após a publicação do livro, ele explica sua opção por tratar a libertação sob a dimensão do belo e do poético. Neste, a imaginação passa a ocupar o centro de sua reflexão:

Tanto que, se fosse reescrever o livro, incluiria um capítulo sobre "A Função Política da Beleza". É que acredito que as pessoas lutam melhor quando são possuídas por visões de coisas belas. E é por isto que não posso imaginar uma teologia da libertação que não se apresente como coisa estética, obra de arte, fragmento de paraíso, sacramento de coisa saborosa. Quero uma teologia que esteja mais próxima da beleza que da verdade, porque da visão da beleza surgem os amantes, mas sobre a convicção da verdade se constroem as inquisições (ALVES, 1986, 19, 20).

A ideia de imaginação, utilizada na teologia noturna de Rubem Alves e também - como veremos adiante - mais intensamente nas suas crônicas e na literatura infantil, é aquela desenvolvida por Bachelard, a qual deve ser pensada como fator determinante para o conhecimento. Alves mesmo se define: "Não penso a partir de conceitos. Penso a partir de imagens. Meu pensamento se nutre do sensual. Preciso ver. Imagens são brinquedos dos sentidos. Com imagens eu construo estórias" (2005, p. 81).

Rubem Alves é um teólogo crepuscular. É por isso que ele fala de saudade, contemplação, beleza. A religião afetada pela poesia mora nessa crepuscularidade e logo mostra-se em seu esplendor, pois “o crepúsculo, a tristeza-bela, faz-nos ver coisas invisíveis que moram no mundo da memória e no das esperanças. 
É por isso que no crepúsculo o mundo se torna um lugar mágico e secreto" (ALVES, 1982, p. 19).

Assim, nessa teologia noturna, imaginação e ilusão são categorias antinômicas. A imaginação é a atividade humana, a qual conduz a humanidade para a sua libertação; por sua vez, o seu antônimo, a ilusão, é o suspiro do humano oprimido que perdeu a esperança em seu horizonte histórico e, por conseguinte, adaptou-se aos ditames dos opressores.

O marco desse crepúsculo, isto é, da passagem do dia para a noite, é a já mencionada obra Tomorrow's Child. Para exemplificar, cabe recorrer à crítica feita a Rollo May. Para esse psicanalista, o norte-americano que viveu antes da Primeira Guerra Mundial era possuidor de uma dupla característica: tratava-se de indivíduo introvertido, que interiorizava as regras externas, mas também era um indivíduo talhado para os negócios. O fim desse norte-americano, o qual nomeou de homem-giroscópio, ${ }^{10}$ após a grande guerra, deixou um significativo de vazio na sociedade contemporânea. O epitáfio feito por Rollo May ao homem-giroscópio tornou-se a metáfora crítica de Alves à sociedade tecnológica e moderna. Rollo May disse: "Como o dinossauro, ele teve poder sem a capacidade de evoluir, e força sem a capacidade de aprender" (MAY, 1987, p. 18). A partir desse epitáfio, Alves constrói um paralelo imaginativo, poético, a respeito da civilização tecnocrática, utilizando as figuras dos dinossauros e das lagartixas.

O teólogo argumenta que os dinossauros não sobreviveram na História por causa de seu gigantismo enquanto as lagartixas, "parentes subdesenvolvidas dos dinossauros", escaparam ilesas e "assistiram, solenes, aos funerais dos primos fortes” (1986, p. 25). A razão da sobrevivência foi, paradoxalmente, sua fraqueza e pequenez. A relação de semelhança é estabelecida com a nossa civilização moderna, a qual se destaca pelo seu gigantismo e por sua necessidade cada vez maior de energia para sobreviver. ${ }^{11}$

De acordo com Rubem, a nossa civilização não se dispôs a analisar os riscos relativos ao seu crescimento, ainda que vejam os primeiros sinais evidentes, como a poluição, a destruição do meio ambiente, os problemas da metrópole e a expansão armamentista. E, tampouco, percebera um fato óbvio: uma economia que não cresce é uma economia em crise e estagnada. Assim, há a constatação

\footnotetext{
10 Rollo May nomeou o homem norte-americano que viveu antes da guerra de homem-giroscópio (Cf. MAY, R. O homem à procura de si mesmo. Petrópolis: Vozes, 1987, p. 17).

11 Em 1992, Rubem lançaria um livro infantil Lagartixas e dinossauros, com ilustração de André Ianni, publicado pela Loyola. E assim, transformou seu argumento teológico numa atrativa história para crianças.
} 
de uma contradição entre a exigência de crescimento constante e o fato de os recursos planetários serem limitados. E, sentencia que todo processo de crescimento chegará ao cenário caótico em que as necessidades serão maiores que os recursos naturais. "Quando isto ocorrer, o sistema entrará em colapso. Foi o que aconteceu com o dinossauro" (IDEM p. 26). Assim, Rubem Alves proclama, em Tomorrow's Child a imaginação como experiência contracultural necessária na civilização cujo ponto nodal é a produtividade.

Embora na medida em que os anos se passaram Rubem Alves tenha escrito um menor número de livros e artigos teológicos, o campo religioso continuou o centro das suas preocupações. Esse interesse se manifestaria também nos escritos não acadêmicos, como nas crônicas e nas histórias infantis. E, nessas expressões literárias, nas quais a imaginação criadora é fonte de reflexão e produção do conhecimento, a teologia noturna continua a operar de modo incidental.

Jorge Luis Borges, em seu livro O outro, conta um encontro que ocorrera em um simples banco de praça às margens do rio Charles, em Boston. Nesse episódio narrado, o velho Borges senta-se, casualmente, ao lado do jovem Borges. Os dois iniciam uma conversa difícil. Um olha para o passado, o outro para o futuro. O desenrolar do diálogo atesta a mudança ao longo dos anos, contudo, certos aspectos sobrevivem à passagem inexorável do tempo. Os gestos transformamse, mas não as causas pelas quais a existência é dedicada. É por isso, e este tem sido um dos argumentos dessa tese, que refutamos a história de vida, a trajetória pessoal, como um acúmulo contínuo de dados históricos.

A mudança de Rubem Alves ao longo da vida é perceptível, apesar disso, ele continuou sendo o mesmo. $\mathrm{O}$ caminho poético que preferiu trilhar não o distanciou de suas obsessões.

Para exemplificar, cabe recontar um acontecimento. Quase 25 anos depois de defender sua tese doutoral e de se tornar arauto da libertação, volta a participar de um encontro internacional de agências de trabalho assistencial com comunidades pobres. ${ }^{12}$ Nessa reunião, Rubem continua a exigir uma mudança de rumo, no entanto, agora com apelação poética e um convite ao que chamara lógica do pražer. Disse: “...[o] problema não é somente ajudar as pessoas, é ressuscitar os mortos. E os corpos mortos ressuscitam pelo poder da beleza”. E, sua demonstração prossegue com o argumento de que uma das chaves postas em prática pelos gregos para a superação da tragédia humana fora a conquista da beleza; o cristianismo, por sua vez, segundo Alves, evita a poesia, a beleza, e insiste na máxima paulina “justificação pelas obras” para aplacar o sofrimento.

12 Reunião da Presbyterian Health, Education and Welfare Association (PHEWA), sediada em Albuquerque New Mexico, fev. 1993. 
Ao aceitar o risco de ser bufão em tal reunião, Alves julgou teologicamente o ativismo das agências assistenciais que continuam promovendo o paternalismo entre as pessoas necessitadas. Questionou também a efetividade (e utilidade) de seus projetos numa libertação autêntica, integral, que inclua a projeção e a realização dos sonhos, algo muito alheio aos planos desse tipo de instituições. (...) Não se renunciou às antiga causa, mas agora esta se situa em coordenadas mais humanas, que colocam a ação libertadora em um plano mais existencial que pragmático. Trata-se, portanto, de uma teologia radical da libertação, que procura ressuscitar a humanidade com base na beleza (CERVANTEZ-ORTIZ, 2005, p. 158).

O percurso kenótico alvesiano é esse exercício de esvaziamento da teologia dos seus conteúdos dogmáticos e seu acesso por meio da poética. $\mathrm{O}$ excesso de luz, racionalismo característico das diversas teologias tradicionais, paulatinamente dá lugar ao crepúsculo. Nestes, as diversas cores, ou as várias faces do "mesmo" Rubem expressam o seu apreço à beleza em detrimento da venerada aplicabilidade teológica. ${ }^{13}$

Teologia é uma música que eu faço com palavras, um móbile de contas de vidro, uma tapeçaria de luz. Faço por razões estéticas. E é por isso que nem necessito crer. Teologia deveria ser sonata tocada com palavras. Todo teólogo deve ser bom músico. Do cristianismo, o que sobrou de mim foi a música. Basta ouvir Bach ou Handel para que eu fique possuído, a despeito da estática produzida pelos dogmas e doutrinas das igrejas, que só ofendem a minha razão. Minha fé é estética. É um amor à beleza. A beleza é divina. Ao ouvir música de outras tradições, percebo que Deus tem muitas belezas diferentes... (ALVES, 2010, p. 128).

Essa teologia do cotidiano emerge do desencanto institucional e fabula sobre as ausências e os prazeres da vida. Assim, aproxima-se das brincadeiras infantis, da magia e da beleza. Prefere ser associado a mágicos e cozinheiros que à teologia. Como afirmou em seu livro cuidadosamente intitulado de Variaçôes sobre a vida e a morte: ou o feitiço erótico-herético da teologia:

13 A "aplicabilidade teológica" é questionada por Rubem Alves, em história publicada na Revista Tempo e Presença (mai. 1987) a qual nomeou de "O galo". Nessa história, ele compara os teólogos profissionais a um galo convicto de que seu cantar era a causa do nascimento do sol a cada manhã. Em um dia como os outros, ele dorme além do esperado e não canta; contudo, para a sua surpresa o sol nascera. Assim, por mais grandiloquentes que sejam os discursos teológicos, eles não exercem influência nos céus. 
Por malditos que são, nossos desejos passaram a ser não-ditos, e assim eles têm de dizer sob a máscara das metáforas e das metonímias, sob a proteção das névoas e inversões dos símbolos oníricos, aparecendo como criaturas secretas e noturnas, ou fantasiados nos carnavais da arte, da poesia, das canções, do humor, das procissões, das romarias, dos rituais mágicos, das religiões populares, das festas, das celebrações...

E o teólogo, pastor de esperanças, descobre que, a fim de realizar seu destino, é necessário primeiro frequentar os desejos dos homens de mãos vazias, irmãos do Cristo, local de revelação, colhendo-os e recolhendo-os com olhos e ouvidos extasiados, em busca da confissões de amor que eles contêm. Porque é dessa matéria-prima que sua fala vai sair, apenas para dizer em voz alta aquilo que as profundezas dos homens geraram sem poder dizer (ALVES, 2005, 153).

A afinidade entre magia e esperança já fora realçada por Malinowski (1972). Para este, a magia é uma expressão da esperança, através dela os segredos podem vir à tona. "Onde quer que a realidade torne ao homem impossível criar com as próprias mãos o desejo de seu coração, ainda assim ele preserva e vive suas aspirações através da ação simbólica." ${ }^{14}$ Logo, a intenção da magia não é descrever o mundo fidedignamente, mas sugerir como ele deveria ser. O homem pratica a magia por sua recusa no mundo, tal qual ele se apresenta.

Em Rubem Alves, a magia possui uma significação profética. Ela proclama, por meio do próprio absurdo, que a regeneração social só ocorrerá mediante o aniquilamento das condições desumanas do presente. Contudo, a magia não transformará a realidade enquanto prescindir de um homem impotente. É preciso que a impotência humana não se transforme em poder.

Antônio Carlos de Melo Magalhães, ao discutir a relação entre teologia e literatura, aponta ser Rubem Alves um pioneiro "ao se apropriar de uma forma de fazer teológico que pode ser incluído dentro da teopoética" (2000, p. 144). Ao prosseguir com sua argumentação, o pesquisador da área de literatura evidencia que na teopoética alvesiana a poesia não é mero objeto, pois ela está contagiada de reflexões teológicas. Desse modo, seria na linguagem poética que o saber teológico aflora das ruínas da racionalidade ocidental à qual a poesia foi subjugada. E, ao finalizar sua apreciação da incursão poética da teologia de Rubem Alves, atesta que na teopoética do autor da menina e o pássaro encantado:

O labor teológico não se contenta com a racionalização de práticas no campo da moral e da ética nem com o aprisionamento de Deus dentro dos conceitos.

14 Malinowski, B. O problema e o significado em linguagens primitivas. In: Ogden, C. K. \& Richards, I. A., 1972, p. 91. 
Ele alça voo em direção a uma verdadeira arte no uso da linguagem, revisita a habilidade com a palavra, deixa-se levar pela criatividade livre da estética, propondo uma união entre beleza e verdade (IDEM, p. 148).

\section{Fabular mundos: política da existência}

É simplista designar Rubem Alves apenas como um idealista. Para além disso, é preciso atentar para o uso que faz da literatura como negação da esterilidade das condições materiais ou decorrências históricas. As impossibilidades materiais, por meio da poética alvesiana, abrem-se para um excesso de possíveis. A respeito disso, cabe trazer Slavoj Zizek à nossa conversa:

...o fluxo de sentido é um teatro de sombras, mas isto não significa que possamos negligenciá-lo e concentrar-nos na "luta real" (...) em última instância tudo é decidido aqui (...) A afirmação da "autonomia" do nível do sentido é, não um compromisso com o idealismo, mas a tese necessária de um verdadeiro materialismo (...) Se subtrairmos este excesso imaterial não obteremos um materialismo reducionista, mas um idealismo encoberto (ZIZEK, 2001, p. 31, 32).

É nesse contexto semântico que Deleuze defende ser a expressão algo maior que uma sublimação dos nossos desejos falidos. Para ele, a literatura é máquina entre máquinas, e o escritor emite corpos reais. Dito de outro modo, escrever, falar e pensar são atos oriundos de atos políticos fundamentais - "para além das teorias do estado e das doutrinas do consenso" (PELLEJERO, 2008, p. 63). Em seu livro A Crítica e a Clínica, Deleuze retoma a noção bergsoniana de fabulação e confere a essa categoria um sentido político.

Escrita e fabulação diferem estrategicamente de uma abordagem material das causas e efeitos, assim como a noite difere estrategicamente do dia. Esse ato político existencial traça uma linha de fuga e propicia a reconfiguração dos territórios que atravessa.

...a máquina literária antecipa uma futura máquina revolucionária, não por razões ideológicas, mas porque só ela está determinada a preencher as condições de uma enunciação coletiva; condições das quais carece o meio ambiente em todos os demais aspectos (...) Não há sujeito, só há agenciamentos coletivos de enunciação; e a literatura expressa estes agenciamentos nas condições em que não existem no exterior, onde existem apenas enquanto potências diabólicas do futuro ou como forças revolucionárias por construir (DELEUZE, G. \& GUATTARI, 1975, p. 31, 32). 
A teologia crepuscular ${ }^{15}$ amplificou o discurso de Rubem Alves. Sua fabulação permitiu que as reflexões em torno da esperança e da libertação estivessem presentes em histórias infantis, crônicas do cotidiano e pensamento educacional ou psicanalítico. E, na medida em que se aproxima desses novos leitores, o pensamento alvesiano reconfigura novos territórios. Sua opção pela fabulação literária não deve ser pensada como um escape ao mundo factual, como sugerem alguns críticos, ${ }^{16}$ mas como criação de condições para a expressão de outros mundos possíveis, os quais podem desencadear a transformação do mundo existente.

Assim, a escrita poética alvesiana é uma expressão política. Uma necessidade da sua existência. Um gesto poético. Fabular novos mundos é trabalho da literatura frente a uma opressão qualquer:

Artaud dizia: escrever para os analfabetos, falar para os afásicos, pensar para os acéfalos. Mas que significa "para"? Não é "dirigido a...", nem sequer "no lugar de...". É "ante". Trata-se de uma questão de devir. O pensador não é acéfalo, afásico ou analfabeto, mas o devém. Devém índio, não acaba de devir, talvez "para que" o índio que é índio devenha ele mesmo algo mais e se liberte da sua agonia (DELEUZE apud PELLEJERO, 2008, p. 72).

As mudanças de cenários oriundas de asfixias políticas, as quais se manifestavam ora no fundamentalismo religioso, ora na dinâmica da política acadêmica, possibilitaram um crescimento pessoal de Rubem Alves. Essa nova sensibilidade para a ação e para o pensamento arrancou do silêncio um devir-poético.

$\mathrm{O}$ acontecimento ${ }^{17}$ que fez emergir essa linguagem poética se deu na

15 Alguns autores, teólogos, que se dedicaram em análises acerca da teologia de Alves, preferem os termos: Teologia do Cotidiano (CERVANTES-ORTIZ, 2005), Teologia incidental (REBLIN, 2012) ou Teologia estético-imaginativa (L, 2012).

16 Aqui, refiro-me ao livro Libertação da teologia, escrito por Juan Luis Segundo. Para esse autor, a teologia alvesiana não está comprometida com a libertação histórica.

17 Utilizo a noção acontecimento oriunda de Deleuze. Para esse filósofo, há dois tipos de tempo. Um deles, o Cronos, diz respeito à mistura de corpos ou estados de coisa e por isso preside a ordem das causas; caracteriza-se pela sucessão de instantes, ou seja, sua gênese deve-se à "forma cíclica do infinito" em que um eterno presente, que contrai todos os instantes, se descontrai em presentes pontuais que são passados ou futuros uns em relação aos outros. Em segundo lugar, há o Aion, que diz respeito aos incorporais e por isso é caracterizado pela fuga incessante do presente, seja no sentido do passado seja no sentido do futuro, ou melhor, sua gênese deve-se à "forma da linha reta ilimitada". A partir dessas configurações relativas à temporalidade, o problema deleuzeano será o de acoplar o tempo cíclico infinito ao tempo retilíneo ilimitado, por esse motivo o acontecimento será nomeado como a instância que participa de ambos os registros temporais, de modo que haja encarnação dos acontecimentos nos corpos e estados de coisa, bem como, acontecimento puro, caracterizado nas palavras de Deleuze como "sempre qualquer coisa que acabou de passar ou que vai se passar, simultaneamente, jamais qualquer coisa que se passa" (DELEUZE, 1969, p. 79). 
experiência de paternidade vivenciada a partir do nascimento de Raquel. A intenção era transformar dor em beleza. E, diante da necessidade de superar o receio de uma cirurgia necessária para corrigir o problema da filha, escreveu um dos seus primeiros livros infantis: Operação Lili. Trata-se da história de uma elefantinha, Lili, que precisava fazer uma operação para retirar Gregório da sua tromba, seu amigo sapo, que lá foi parar após uma brincadeira. Lili estava cheia de medos, mas uma fadinha, a Fada da Floresta, a ajudou a superá-los, fazendo-a dormir para que tivesse vários sonhos bonitos enquanto a operação acontecia. Desse modo, Lili não sentia dor alguma e, quando acordou, seu amigo Gregório já estava salvo, além de muito contente. Lili ficou feliz por ter salvo o amigo.

A criança que morava em Rubem ganhou voz à medida que contava histórias para a sua filha Raquel. Uma vez, Rubem ia se ausentar do Brasil por um longo período. Com apenas 4 anos de idade, e muito ligada ao pai, Raquel estava desolada. Por isso, para explicar a sua ausência temporária, Rubem escreveu $A$ menina e o pássaro encantado. Nesse livro, uma menina não suporta a saudade e para impedir que o pássaro voasse, tratou de prendê-lo numa gaiola. Por esse motivo, o pássaro deixou de ser encantado, esqueceu o seu canto e perdeu suas cores. $\mathrm{O}$ pássaro só era encantado enquanto estivesse livre. A esse respeito, ele comenta:

Criar história para minha filha virou um hábito e um prazer. Era um trabalho de parceria: ela inconscientemente oferecia o tema; eu refletia durante alguns dias, criava o enredo e depois apresentava à Raquel uma versão poética de suas angústias e ansiedades (Apud NUNES, 2002, p. 212).

Uma das marcas da literatura é a sua capacidade plurívoca. Ela evoca múltiplas interpretações. Apesar de o autor dessa história infantil buscar tratar apenas da distância entre seres que se amam, outros sentidos passaram a ser atribuídos à história. Esse livro:

Começou a ser usado por terapeutas para lidar com casais em que cada um tentava engaiolar o outro. Depois, os educadores argumentavam que as escolas são como gaiolas que prendem os alunos. E também por religiosos que me felicitavam por eu ter escrito uma linda estória sobre Deus. Sobre Deus? Você se pergunta. Ele disse que o pássaro encantado era Deus e as religiões que o aprisionam eram as gaiolas. É... pode ser. Não podemos engaiolar o sentido. ${ }^{18}$

18 Entrevista concedida ao autor do artigo para pesquisa doutoral em novembro de 2012. 
Desde então, seus livros, além de aceitos pelo seu público eleito, têm sido adotados por professores do ensino fundamental e até indicados por psicólogos infantis para que temas considerados de difícil tratamento possam ser trabalhados com as crianças.

Vários desses livros estão organizados em torno de uma coleção chamada de Estórias para pequenos e grandes, a qual até o momento, reúne 13 livros. Merece destaque a visão do indivíduo não fracionado em faixas etárias. Rubem Alves, ao abordar temáticas incomuns ao público infantil, reconhece a dificuldade em tratar de maneira simplificada sobre determinados assuntos, como: a doença, a morte, a separação. Assim, nesse contexto literário, Alves singulariza-se, ao tentar falar para crianças ou adultos, sem fazer concessões na linguagem.

Em $A$ selva e o mar, livro no qual se discute a separação de pais, Rubem admite a complexidade da temática e que não conseguira comunicar essa problemática de uma forma infantil. Embora ele mesmo tenha considerado esse "um livro difícil", especialistas consideraram a linguagem adotada uma virtude, "já que falar de temas complexos de maneira simples é tentar simplificá-los. O esforço de simplificação em nome da comunicabilidade fácil, na maioria das vezes, resulta em uma não-comunicação. Há assuntos não-comunicáveis, indizíveis mesmo, e simplificar seu tratamento é banalizá-los". ${ }^{19}$

Em sua literatura para o público infanto-juvenil, Rubem Alves busca contestar a fantasia de uma infância feliz, unicamente lúdica e imaginativa, nas quais conteúdos tristes são proibidos. Não acidentalmente há na introdução de todos os números da coleção, uma advertência: “O mundo das crianças não é tão risonho quanto se pensa. Há medos confusos, difusos, as experiências das perdas, bichos, coisas, pessoas que vão e não voltam...” (ALVES, 1985, p. 5).

Pelos motivos já expostos, as histórias de Rubem Alves são escritas para serem contadas por alguém. Esse contador pode atuar como um facilitador no conflito. Ele pode, no momento de tensão ou perigo exacerbado pela narrativa, reafirmar sua presença junto à criança. Sobre esse aspecto, percebe-se a valorização do livro como lugar do saber e da experiência e o momento da leitura como espaço de fortalecimento dos vínculos afetivos e da cumplicidade. Se o medo não pode ser aplacado pelo objeto livro, pode sê-lo por quem o utiliza: o contador/leitor das histórias, mediador entre o autor e o leitor final.

O jovem leitor de Alves é frequentemente convidado a aprender a encarar a inclemência dos abismos da vida como quem enfrenta as agruras próprias a

19 Batista, S. S. S.; Wenzel, M. C. R. A concepção de infância na literatura infantil. Revista Comunicação e Educação, ECA-USP, v. IX, p. 32-42, 2006. 
uma paisagem nativa. Entre a planície e a montanha encantada há um caminho previamente traçado, o qual pode ser reinventado. Afinal, não é a montanha encantada, mas o próprio indivíduo quem precisa identificar e seguir sua trajetória sozinho. Rubem fala ao seu leitor do desamparo do indivíduo, recuperando o belo. Sobretudo, apontando a prevalência da esperança.

Em Como nasceu a alegria, Rubem Alves relata como era a Terra há muitos anos e a compara a um exuberante jardim, cujas flores eram todas lindas e vaidosas. A competição entre as flores era frequente no que tange à beleza de cada uma. Tal ambiente belo e infeliz fora abalado, visto que uma "florinha", ao nascer, cortara uma de suas pétalas num espinho. Inicialmente, a "florinha" nem ligou e vivia muito feliz. No entanto, com o passar do tempo, começou a perceber que as outras flores a olhavam "com olhos espantados". E a partir desse momento, percebeu sua diferença.

A "florinha” não chora ao perceber que possui a pétala rasgada, mas porque percebe a diferença nos olhos das outras flores. A história de Rubem Alves fornece símbolos que permitem enunciar os medos e os anseios humanos. A "florinha" da pétala rachada, ao ser vista com estranheza e compaixão, experimenta o gosto da autopiedade e chora. E seu pranto, conduz todos às lágrimas e do pranto de todos nascem a chuva, os rios e os mares.

Como nascen a alegria sugere um caminho, o qual o leitor/ouvinte pode seguir para enfrentar as diferenças e redirecionar o seu olhar. O objetivo da história é argumentar que não se deve pensar na diversidade como algo que priva, que exclui, que limita, mas, simplesmente entender que a beleza advém daquilo que difere e não do que iguala. Dessa perspectiva nasce a alegria, e dela o olhar que acaricia, acolhe e inclui.

Alguns consideram que entre os grandes empreendimentos alvesianos, a literatura para crianças é a mais brilhante..$^{20}$ Em entrevista, o filósofo francês Roger Garaudy considerou Rubem Alves no mesmo patamar que Antoine de Saint-Exupéry.

Reafirmo, em Rubem Alves literatura é política de existência. Assim, ele considera o conselho de Nietzsche e encara a fabulação literária com a mesma seriedade que uma criança lida com uma brincadeira. E, por isso, os modelos mentais apreendidos ao longo da sua formação teológica e vivência pastoral estão presentes nas analogias ao longo desses textos. Suas histórias trazem uma marca que pode passar desapercebida no leitor comum: a teologia negativa.

$20 \quad$ Morais, Regis, 2007, p. 107. 
Se a teologia afirmativa prescreve os atributos de Deus, ${ }^{21}$ a teologia negativa, contrariamente, nega essas propriedades divinas. Não obstante, longe de incorrer em aberta contradição, os métodos catafático e apofático possuem um papel correlativo. Mas em que sentido? É evidente que não se trata simplesmente de negar o que tinha sido afirmado de Deus, mas, sim, de uma clara e "racional" percepção de que Deus transcende infinitamente as possibilidades do conhecimento humano. Explico. O método negativo, ao contrário do afirmativo, é ascendente e as negações se elevam dos atributos mais humildes aos mais nobres: "pois quanto mais nos elevamos ao alto, tanto mais as palavras se contraem ao divisar e contemplar os seres inteligíveis". ${ }^{22}$ É preciso notar que a teologia negativa (apofática) abre a trilha para a teologia mística, de modo que é difícil distinguir factualmente onde uma termina e a outra começa.

A deidade da teologia mística ou teologia negativa; seriam, ambas, acessíveis obliquamente, isto é, de maneira indireta, apenas por meio de suas manifestações ou expressões fenomênicas.

Nesse contexto expositivo, é útil recorrer à abordagem psicanalítica bioniana, a qual se afasta da formulação de teorias explicativas, difusoras de um conhecimento generalizador, objetivo e exato. Essa perspectiva busca a formulação de modelos epistemológicos por analogia, os quais afirmam e negam simultaneamente. Ao optar por esse formato de escrita, Rubem abre espaço para futuras reformulações e desenvolvimento de outros modelos. Nas palavras de Antônio Muniz Rezende:

A capacidade negativa, segundo Bion, no presente contexto é a capacidade de usar as teorias psicanalíticas sem se escravizar a elas, mas conservando a liberdade de pensamento (correspondente à liberdade de associação do paciente). É ser capaz de usá-las, mas conservando a capacidade de negar o que foi afirmado, por reconhecer que, de acordo com Bion, nem a melhor teoria é continente adequado para a experiência psicanalítica (REZENDE, 2000, p. 155).

$\mathrm{Na}$ introdução a Atenção e Interpretação, Bion adverte sobre a necessidade de distinguir a experiência emocional da sua comunicação ou verbalização, e enfatiza o caráter analógico de suas próprias teorizações sobre o processo de transformação/interpretação da experiência analítica. O importante é considerar

\footnotetext{
21 Atributos como o Bem, o Ser, a Beleza, a Vida, o Saber.

22 De Boni, L. A. (Org.). Lógica e Linguagem na Idade Média. Porto Alegre: Edipucrs, 1995, p. 47-54.
} 
que as descrições ou símbolos que ele utiliza para tal tarefa diferem daquilo que eles representam. A analogia, nesse contexto, baseia-se na relação entre determinados objetos e não nos objetos em si.

A religião para Rubem foi, e é, uma experiência alquímica (tanto objetiva, quanto subjetiva). É nela, dela e por ela que sua vida se reinventou ao longo dos anos. Ela (a religião) é o cenário da trama da sua existência. E, por isso, não se ausentaria numa produção literária livre.

Longe das amarras de uma teontologia, Rubem continua a falar do divino. Em seus livros poéticos-literários, o Deus que emerge é abissal. Uma divindade inacessível pelo conhecimento, ser que se furta a toda conceptualização. Por isso, a paixão pelo paradoxo, pelas antinomias e pelas expressões opostas.

Assim entendida, essa teologia negativa adotada por Alves em sua literatura infantil e presente também em algumas crônicas é um método de "superafirmação". Ela é um além categorial, uma espécie de katharsis dos nossos conceitos humanos. É preciso situá-la no âmbito de uma afirmação transumana, pois seu objeto escapa a todas as nossas categorias, a todas as nossas afirmações e a todas as nossas negações. A afirmação só valerá na medida em que for penetrada pela preferível negação, que orienta diretamente para o Inefável.

Em tempo, essa "capacidade negativa" não deve ser lida e compreendida como sinal de ceticismo. Ao contrário, deve ser percebida como uma decorrência da fé. É expressão de uma atitude aberta - proporcionada pela adoção de um pensamento simbólico - e, respeitosa, em desdobramento de uma experiência relativizadora.

A crônica notabiliza-se por ser um gênero narrativo autônomo com amplitude semântica e estética. Isto é, ao contrário dos textos acadêmicos, ela não se constitui num texto fechado. É uma expressão literária plurívoca. A etimologia, chronus, sugere que a crônica guarda vinculação com tempo. Via de regra, é um texto curto, em prosa, publicado em jornal ou revista; daí o seu caráter volátil. Sua narratividade em primeira pessoa faz dela um gênero confessional por excelência. Outro aspecto que merece destaque reside no fato de a crônica permitir ao seu autor um diálogo mais efetivo com o leitor, num ritmo mais leve, cuja linguagem pode envolver poesia, fantasia, lirismo.

Muitas das crônicas de Rubem Alves foram publicadas, inicialmente, no Diário Popular de Campinas e, posteriormente, no Correio Popular de Campinas, na Folha de S. Paulo ou no Estado de S. Paulo. Posteriormente, compiladas em livros, entre os quais destacamos: O retorno e terno; Sobre tempo e eternidade; Cenas da vida; Estória de quem gosta de ensinar, Entre a ciência e a sapiência; O dilema da educação; 
Educação dos sentidos; As cores do crepúsculo; Navegando; Na morada das palavras; Quarto de badulaques; Mais badulaques, Ostra feliz não faz,pérola; entre outros.

Um dos mais conhecidos cronistas, Carlos Drummond de Andrade, publicou no jornal Folha de S. Paulo, em 14 de setembro de 1978, um texto que nomeou $O$ frivolo cronista. Nele, o poeta, também mineiro, faz uma provocação a respeito da sua função de cronista e sugere uma superficialidade necessária à crônica para traduzir a simplicidade do cotidiano.

O inútil tem sua forma particular de utilidade. É a pausa, o descanso, o refrigério, no desmedido afã de racionalizar todos os atos de nossa vida (e a do próximo) sob o critério exclusivo de eficiência, produtividade, rentabilidade e tal coisa. Tão compensatória é essa pausa que o inútil acaba por se tornar da maior utilidade (...). Não devemos cultivar o ócio ou a frivolidade como valores utilitários de contrapeso, mas pelo simples e puro deleite de fruí-los também como expressões de vida. No caso mínimo da crônica, o auto-reconhecimento da minha ineficácia social de cronista deixa-me perfeitamente tranqüilo. O jornal não me chamou para esclarecer problemas, orientar leitores, advertir governantes (...) ditar normas aos senhores do mundo (...). Contratou-me e não vejo erro nisto, por minha incompetência e desembaraço em exercê-la.

Ao que parece, Drummond alude à inutilidade da crônica num sentido alegórico. Os excessos de compromissos deixam os indivíduos incapazes de enxergar as coisas simples da vida. A sua rotina os absorve para as coisas graves da vida. Assim, o papel da crônica é apontar para a inutilidade, preocupar-se com o belo presente nas situações corriqueiras do dia a dia.

Ainda sobre a afirmação de Drummond e sua tentativa de traduzir o ofício de cronista, cabe ratificar que esse tipo de linguagem está descomprometido com quaisquer obrigações formais ou rígidas, uma vez que a crônica configura-se como uma narração, na qual seu autor tem total liberdade ao escrevê-la.

Assim, a crônica engendra-se como um gênero eivado de autonomia estética, pela sua intensa carga semântico-discursiva e, por conseguinte, pela sua capacidade de trabalhar os diferentes temas com os mais diversos recursos linguísticos, produzindo uma pluralidade de sentidos que convém a cada um desvendar e vivenciar.

Em $A$ intuição do instante, Rubem parece ter encontrado um componente fundamental para a sua afeição às crônicas. Trata-se da concepção de tempo de Gaston Roupnel, o qual compreende o tempo como realidade imediata, algo como uma potência absoluta na qual se inscrevem os acidentes possíveis - o 
instante. Essa filosofia opunha-se à de Henri Bergson, que explicava o tempo como uma duração, isto é um "artifício", ou ainda, uma construção feita "do exterior" pela memória.

Ora, é justamente com essa concepção contínuo-espacial entre memória, percepção e duração que as crônicas alvesianas procuram romper. De modo análogo a Gaston Bachelard, Rubem recorrentemente presume o caráter dramático do instante como condição de inteligibilidade do presente. Dito de outra maneira, o presente aponta em suas crônicas não mais como um estado hipotético da consciência, mas como um ponto de partida instável e instantâneo, a partir do qual passado e futuro efetivam-se.

Ao ter como horizonte a crônica como espaço poético para executar a intuição do instante, Rubem Alves faz do presente um ato inaugural e do tempo, uma síntese de ritmos, de coincidências, de similitudes e de diferenças. Não à toa, comumente, a memória surge, como ato e não como ação e desse modo desvela toda sua potencialidade imaginativa. Ela não se restringe a um depositório de imagens sensoriais e se apresenta como um trabalho de evocação.

Tal qual a proposição bachelardiana, pensar o tempo é um ensaio de consolidação da experiência segundo uma ordem desejada. Essa ordem, no caso do cronista Rubem Alves, é dada pelos itinerários e ocupações afetivas dos espaços de seu pertencimento. Por isso, possibilita deslocamentos narrativos que podem, instantaneamente, não fazer sentido ao seu interlocutor. No entanto, ao expor que seus acontecimentos guardam instantes poéticos de irrupção de afetos a memória ultrapassa instantes superficialmente pontuais ou isolados e consolida intervalos de duração. Tecidos afetivamente pelo pensamento. Esses intervalos produzem o sentido da experiência narrada e a inscrevem existencialmente nos leitores desse gênero literário.

O ingresso de Rubem nesse tipo de literatura se deu ainda na década de 1980. A Revista Tempo e Presença o convidou para que escrevesse mensalmente sobre temas de sua preferência. Em formato livre, e não necessariamente textos analíticos como os demais que compunham a publicação. Assim, por 17 anos, Rubem Alves inicia como cronista. Lançou-se, em definitivo, a um público não evangélico com Conversas com quem gosta de ensinar e Estórias de quem gosta de ensinar. Com essas publicações, ganharia notabilidade sua percepção de educação.

Em seus textos, Rubem Alves toca em uma intensa diversidade de assuntos oriundos da vida cotidiana: Deus, religião - suas temáticas preferidas - felicidade, educação, ideologia, morte, solidão, velhice, sexo. Todavia, o tom professoral (ou seria pastoral?) de alguém preocupado com a formação do indivíduo está sempre presente. $\mathrm{O}$ interesse de educar pela beleza, pelos sentidos. 
À semelhança de Bachelard, o mineiro da Boa Esperança reconhecia, deleitava-se e estimulava as alegrias do ver. Ao mencionar um notável ensaio do epistemólogo francês chamado "Introdução à Bíblia de Chagall”, Rubem afirma assentir com a afirmação "O paraíso é, antes de tudo, um belo quadro", ${ }^{23}$ mas atenta para as armadilhas inerentes ao olhar. E adverte: "Para se ver bem é preciso estar longe do objeto. Somente os míopes veem de perto. Isso é o contrário do comer: para se comer é preciso que o objeto esteja perto, muito perto". ${ }^{24}$ De um modo, ou de outro. A relação com mundo é realçada pelos sentidos.

Em 2007, a UNICAMP, realizou um encontro-homenagem sobre o legado de Rubem Alves. Na ocasião, ao comentar a respeito das crônicas e sua relação com o pensamento educacional do filósofo-cronista, o Professor Severino Antônio Barbosa atentou para o fato de que os textos alvesianos "valorizam mais o afeto do que o raciocínio lógico, valorizam mais a imaginação do que as informações, valorizam mais a intimidade dos vários mundos que existem dentro de nós do que a utilidade, a funcionalidade; valorizam mais a centelha intuitiva do que a elaboração cartesiana".

Obviamente, não é intenção deste trabalho uma apreciação arguta das crônicas escritas por Rubem Alves. No entanto, para efeito argumentativo, cabe mencionar um aforisma presente em diferentes crônicas: "O homem deve reencontrar o Paraíso...". Esta afirmação está incluída no livro Entre a ciência e a sapiência; assim como em $A$ arte de ver, também está em Sobre a morte e o morrer, crônica publicada em $\mathrm{Na}$ morada das palavras.

Em crônica homônima ao aforisma $O$ homem deve reencontrar o Paraíso, o autor narra a história de uma grande e unida família, a qual cansada da vida na cidade grande, se considerava "moscas presas na enorme teia de aranha que é a vida da cidade", resolve navegar. Para isso, fora preciso um rebuscado planejamento e um longo aprendizado. Cada um especializou-se em algo relativo à navegação. No final, veio a pergunta: Para onde ir? Compreenderam que a escolha do destino era difícil; era necessário conciliar as diversas sugestões, o gosto de cada um. "Se os barcos se fazem com ciência, a navegação se faz com sonhos." ${ }^{25}$

Essa história é emblemática por exemplificar o teor da crítica ao cientificismo, semelhante às críticas feitas por ele ao fundamentalismo religioso. A saída para o iminente aprisionamento de ambas é a construção de utopias.

\footnotetext{
23 Bachelard. O direito de sonhar. Rio de Janeiro: Bertrand Brasil, 1994.

24 Alves, Rubem. Variações sobre o prazer. São Paulo: Editora Planeta do Brasil, 2011.

25 Alves, Rubem. "O homem deve reencontrar o paraíso." In: Entre a ciência e a sapiência: o dilema da educação. São Paulo: Edições Loyola, 1999, p. 73-77.
} 
$\mathrm{Na}$ simplicidade de sua linguagem, próxima do coloquial, Rubem Alves consegue trazer o leitor para junto de si e refletir sobre a realidade que está sendo por ele questionada. "O lastro referencial de seus textos faz o leitor buscar o sentido da vida, ao mesmo tempo em que relacionando o eu ao mundo revela-se o autor psicanalista, mas, acima de tudo, uma pessoa que participa efetivamente do mundo, atento ao que há ao seu redor, um professor-escritor que mantém acesa a chama da esperança em mudanças na educação que valorizem os sonhos, enfatizem a criatividade."336. Desse modo, se a crônica é considerada pela crítica como um "gênero menor" ${ }^{26}$ não deixa de ser uma narrativa que pode, nos acontecimentos do dia a dia, revelar o que há de universal na existência.

Com suas crônicas, entremeadas de textos de autores que ele admira, acontece o que diz Roland Barthes (1982): os textos lidos se tornam escrevíveis; eles não estão ali inseridos como meros elementos de beleza e de erudição, mas eles vêm ampliar ou corroborar as ideias do cronista.

\section{Considerações finais}

Num evento de lançamento do seu belíssimo livro Perguntaram-me se acredito em Deus, durante sua apresentação, Rubem menciona que deixara - havia 35 anos - o pastorado e, desde então, dedicava-se exclusivamente à escrita poética. Concluída a fala, um professor universitário da UNICAMP (não conhecido por Rubem) aproximou-se e disse "quero pedir permissão para corrigir uma coisa que o senhor disse e não é verdade. O senhor continua a ser pastor, o que o senhor escreve é seu cajado e sua flauta".

O Rubem Alves noturno, embora não precise de Deus como objeto do seu pensamento, faz uso da saudade para fazer teologia sob outros formatos (literatura, crônica, poesia). Embora a religião seja um território atravessado, ela é um espaço poético de criação.

Minha teologia não precisa da existência de Deus. Por isto, deixou de ser teologia. Passou a ser poesia. Ela não prova nada. E nem quer. Somente anuncia ausências, objetos para o quais a minha nostalgia se inclina... Demito-me da Teologia. Não tenho nenhuma verdade a compartilhar. Mas ponho o meu corpo na poesia. É só o que tenho a oferecer. ${ }^{27}$

\footnotetext{
26 Candido, Antonio (1978-79). “A vida ao rés-do-chão.” In: Andrade, Carlos Drummond [et al.] para gostar de ler: crônicas. Ed. didática. São Paulo: Ática, 5-13.

27 Tempo e Presença, n. 224, p. 27.
} 
Por fim, outra crônica traz consigo uma advertência aos leitores de Rubem Alves. Em $A$ imagem do rosto, ${ }^{28} \mathrm{o}$ mineiro evoca Jorge Luis Borges para confessar a dimensão narcísica dos seus escritos. Ele deseja rever-se no espelho-textual, a sua obra quer retratar o seu rosto. Por isso, ele adverte: "Cuidado, portanto, ao andar em meio aos objetos que delineiam o rosto de uma pessoa".

\section{Referências}

ALVES, Rubem (Org.). De dentro de um Furacão = Richard Shaull e os primórdios da Teologia da Libertação. São Paulo: Sagarana, 1985.

ALVES, Rubem. A gestação do futuro. Campinas: Papirus, 1986.

ALVES, Rubem. A montanha encantada dos gansos selvagens, 5. ed. São Paulo: Paulinas, 1987.

ALVES, Rubem. A música da natureza, 2. ed. Campinas-SP: Papirus, 2004, 125p.

ALVES, Rubem. Cantos do pássaro encantado: sobre o nascimento, a morte e a ressurreição do amor. Campinas-SP: Verus Editora, 2000, 132p.

ALVES, Rubem. Da Esperança. Campinas-SP: Papirus, 1987, 231p.

ALVES, Rubem. Do universo à jabuticaba. São Paulo: Editora Planeta do Brasil, 2010, 255p.

ALVES, Rubem. Dogmatismo e tolerância. São Paulo: Loyola, 2004, 174p.

ALVES, Rubem. Filosofia da ciência. Introdução ao jogo e suas regras, 11. ed. São Paulo: Brasiliense, 1988, 209 p.

ALVES, Rubem. O sapo que queria ser príncipe (adolescência e juventude). São Paulo: Editora Planeta do Brasil, 2009, 230p.

ALVES, Rubem. O suspiro dos oprimidos. São Paulo: Paulinas, 1984, 183p.

ALVES, Rubem. O velho que acordou menino (infância). São Paulo: Editora Planeta do Brasil, 2005, 269 p.

ALVES, Rubem. Ostra feliz não faz pérola. São Paulo: Editora Planeta do Brasil, 2008, 276 p.

ALVES, Rubem. Pimentas: para provocar um incêndio, não é preciso fogo. São Paulo: Editora Planeta do Brasil, 2012, 215p.

ALVES, Rubem. Pinóquio às avessas. Uma estória sobre crianças e escolas para pais e professores. Campinas-SP: Verus Editora, 2005, 47 p.

ALVES, Rubem. Poesia, profecia, magia. Rio de Janeiro: CEDI, 1983, 81p.

ALVES, Rubem. Por uma teologia da libertação. São Paulo: Fonte Editorial, 2012.

ALVES, Rubem. Protestantismo e Repressão. São Paulo: Ática, 1979.

28 Tempo e Presença, n. 270. 
ALVES, Rubem. Teologia do cotidiano: meditações sobre o momento e a eternidade. São Paulo: Olho D'água, 1994, 95p.

BACHELARD. O direito de sonhar. Rio de Janeiro: Bertrand Brasil, 1994.

BARTHES, Roland. Sollers escritor. Rio de Janeiro: Tempo Brasileiro; Fortaleza: UFC, 1982.

BATISTA, S. S. S.; WENZEL, M. C. R. A concepção de infância na literatura infantil. Revista Comunicação e Educação, ECA-USP, v. IX, p. 32-42, 2006.

CANDIDO, Antonio (1978-79). “A vida ao rés-do-chão.” In: ANDRADE, Carlos Drummond [et al.] para gostar de ler: crônicas. Ed. didática. São Paulo: Ática.

CERVANTES-ORTIZ, Leopoldo. A teologia de Rubem Alves. Tradução: Eleonora Frenkel Barreto. Campinas: Papirus, 2005.

DE BONI, L. A. (Org.). Lógica e Linguagem na Idade Média. Porto Alegre: Edipucrs, 1995, p. $47-54$.

DELEUZE, G.; GUATTARI, F. Kafka: Pour une litterature mineure. Paris: Éditions de Minuit, 1975.

DUSSEL, Enrique. História da Igreja Latino-Americana (1930-1985). São Paulo: Paulus, 1989.

LECOURT, D. Bachelard: Le Jour et la Nuit. Paris: Grasset, 1974.

LUIZ, Rainerson I. E. de. Por uma ordo amoris. Reflexões alvesianas sobre a libertação humana. Dissertação de Mestrado. Pontifícia Universidade Católica do Rio de Janeiro, 2012.

MAGALHÃES, Antonio. Deus no espelho das palavras: teologia e literatura em diálogo. São Paulo: Paulinas, 2000.

MALINOWSKI, B. O problema e o significado em linguagens primitivas. In: Ogden, C. K. \& Richards, I. A., 1972, p. 91.

MAQUEO, Roberto Oliveros-SJ.La humanizacion como creacion y esperanza. Kaantropologia teologica de Rubem Alves. Facultate Theologia Pontificiae Universitatis Gregorianae. Excerta ex Dissertation ad Doctoratum, 105p. 1978.

MORAIS, Regis. O pensamento social de Rubem Alves. In: NUNES, A. V. (Org.). O que eles pensam de Rubem Alves. São Paulo: Paulus, 2007.

NIETZSCHE, Friedrich. Assim Falou Zaratustra. São Paulo: Martin Claret, 2005.

NUNES, A. V. Rubem Alves e a educação dos sentidos: um estudo dos seus pressupostos pedagógicos e filosóficos. Tese (Doutorado em Educação). Faculdade de Educação. São Paulo: USP, 2001.

NUNES, Antônio Vidal. Corpo, Linguagem e Educação dos Sentidos no Pensamento de Rubem Alves. São Paulo: Paulus, 2008.

PELLEJERO, E. Literatura e fabulação: Deleuze e a política de expressão. POLYMATHEIA REVISTA DE FILOSOFIA. FORTALEZA, v. IV, nº. 5, 2008, p. 61-78.

REBLIN, Iuri Andréas. Outros cheiros, outros sabores...: o pensamento teológico de Rubem Alves. São Leopoldo: Oikos, 2009. 
REZENDE, A. M. Ser e não ser sob o vértice de “O”. Taubaté/SP: Cabral Editora Universitária, 1999.

SAFRA, Gilberto. Rubem Alves: o retorno à sabedoria originária. DVD, 95 min. Série: A visão clínica de Gilberto Safra. São Paulo: Editora Sobornost, 2007.

SILVA, Anaxsuell F. Poética da existência: Rubem Alves, história de vida, tramas e narrativas. Tese (Doutorado em Ciências Sociais). IFCH/Universidade Estadual de Campinas, 2014.

SILVA, Anaxsuell Fernando. Da teologia protestante à libertação da teologia: a biografia de um intelectual protestante. Revista Brasileira de História das Religiões, v. 9, n. 27, p. 35-65, jan./ abr. 2017.

XAVIER, Donizete José. A teologia da Santíssima Trindade - Kénosis das Pessoas Divinas como manifestações do amor e da misericórdia. São Paulo: Palavra e Prece Editora, 2005, 178 p.

Submetido em: 24-2-2017

Aceito em: 18-7-2017 